\title{
ANALISIS KEMAMPUAN KOMUNIKASI MATEMATIS SISWA DALAM PEMECAHAN MASALAH MATEMATIKA KELAS XI MA DARUL ULUM SITUBONDO
}

\author{
Ummi Khairiyah ${ }^{1)}$, Darsih Idayani' ${ }^{2)}$, dan Yesi Puspitasari ${ }^{3)}$ \\ ${ }^{1,2,3}$ STKIP PGRI Situbondo, Indonesia \\ umikhoiriyah1299@gmail.com
}

\begin{abstract}
Research to describe communication skills mathematical students in solving mathematics problems class XI MA Darul Ulum 2019/2020 school year. This research is descriptive qualitative research. The subjects in this study were students of class XI MA Darul Ulum as many as 3 students with different levels of communication ability. Data collection in this study uses 4 methods namely; observation, interviews, problem solving tests, and documentation are then analyzed on each data collection method. The results showed that all subjects understand the problem well and have planning and solving problems well, but at low-communication subjects are not good at doing problem solving planning. It shows the wrong results while the subject of high and fair communication ability is showing correct results. It can be concluded that the level of communication skills different mathematical solutions has different problems.
\end{abstract}

Keywords: Mathematical communication skills, Problem solving

\begin{abstract}
Abstrak: Penelitian ini bertujuan untuk mendeskripsikan kemampuan komunikasi matematis siswa dalam pemecahan masalah matematika kelas XI MA Darul Ulum tahun pelajaran 2019/2020. Penelitian ini merupakan jenis penelitian deskriptif kualitatif. Subjek dalam penelitian ini adalah siswa kelas XI MA Darul Ulum sebanyak 3 siswa dengan tingkat kemamuan komunikasi yang berbeda. Pengumpulan data dalam penelitian ini menggunakan 4 metode yaitu; obeservasi, wawancara, tes pemecahan masalah, dan dokumentasi kemudian dianalisis pada masing-masing metode pengumpulan data. Hasil penelitian menunjukkan bahwa semua subjek sudah memahami masalah dengan baik serta mempunyai perencanaan dan melakukan penyelesaian masalah dengan baik, akan tetapi pada subjek berkemampuan komunikasi rendah kurang baik dalam melakukan perencanaan penyelesaian masalah sehingga menunjukkan hasil yang salah sedangkan subjek berkemampuan komunikasi tinggi dan sedang menunjukkan hasil yang benar. dapat disimpulkan bahwa tingkat kemampuan komunikasi matematis yang berbeda mempunyai pemecahan masalah berbeda.
\end{abstract}

Kata Kunci: Kemampuan komunikasi matematis, Pemecahan masalah 


\section{PENDAHULUAN}

Matematika merupakan mata pelajaran yang diajarkan pada setiap jenjang pendidikan. Dengan mempelajari matematika siswa dipersiapkan untuk dapat mengembangkan tingkat berpikir kreatif dan inovatif siswa dengan menggunakan bahasa yang sistematis, mudah dipahami dan dapat menyampaikan didepan banyak orang (Wardhana dan Lutfianto, 2018). Matematika juga merupakan sebuah pelajaran wajib dalam setiap satuan Pendidikan. Sebagian besar fakta yang ada siswa masih mengalami kesulitan dalam belajar matematika, hal tersebut dipengaruhi berbagai faktor yang ada, diantaranya kurangnya semangat dan kurangnya minat siswa dalam belajar matematika. Oleh karena itu, keaktifan dan motivasi dari guru sangat dibutuhkan untuk merangsang keaktifan siswa dalam sebuah pembelajaran (Tefa, Idayani, dan Astindari, 2019). Faktor lain yang menyebabkan siswa mengalami kesulitan adalah kurangnya sosialisasi dan komunikasi yang baik dengan lingkungan sekitar terutama dengan teman sebaya, karena bersosialisasi dan berkomunikasi dalam sebuah kehidupan sosial sangat penting untuk kesejahteraan diri siswa ataupun orang lain.

Kemampuan komunikasi sangat dibutuhkan sehingga siswa dapat mengaplikasikannya dalam proses pemecahan masalah. Penerapan pemecahan masalah dalam pembelajaran matematika juga mampu meningkatkan kemampuan berpikir tingkat tinggi siswa (Abdullah, Abidin, dan Ali, 2015). Pemecahan masalah matematika, menjadi salah satu cara siswa untuk mengembangkan kemampuannya antara lain; membangun pengetahuan matematika yang baru, memecahkan masalah dalam berbagai konteks yang berkaitan dengan matematika, menerapkan berbagai strategi yang diperlukan, dan merefleksikan proses pemecahan masalah matematika (Anggo, 2011).

Dalam pembelajaran matematika terdapat berbagai aspek penting yang perlu dimiliki oleh siswa diantaranya adalah pemahaman konsep dan pemecahan masalah karena hal tersebut menjadi kunci tercapainya tujuan sebuah pembelajaran matematika. Oleh sebab itu, pemahaman konsep menjadi dasar kemampuan dan sangat erat kaitannya dengan pemecahan masalah (Surur, Degeng, Setyosari, dan Kuswandi, 2020). Karena dalam matematika banyak masalah yang mennggunakan logika dan tingkat berpikir yang tinggi untuk sebuah 
penyelesaiannya. Pemecahan masalah merupakan proses kemauan dan keyakinan diri yang tinggi dan memerlukan proses berpikir yang lebih kompleks (Haryani, 2011). Dalam pemecahan masalah terdapat beberapa tahapan, menurut Polya (dalam Husna, Ikhsan, dan Fatimah, 2013) pemecahan masalah mempunyai 4 tahapan yaitu; 1) Memahami masalah, 2) Merencanakan penyelesaian, 3) Menyelesaikan masalah sesuai rencana, 4) Melihat dan mempertimbangkan solusi yang diperoleh.

Kemampuan komunikasi yang baik akan mengantarkan siswa kepada pemahaman dan pemecahan masalah dengan baik pula. Kemampuan komunikasi matematis siswa merupakan suatu cara siswa untuk mengomunikasikan ideidenya dalam usaha memecahkan masalah yang diberikan oleh guru, serta berpartisipasi aktif dalam diskusi, dan mempertanggung jawabkan jawaban mereka terhadap suatu masalah. Berdasarkan dari uraian diatas dan diperkuat oleh fakta yang terjadi di lapangan penelitian ini dilakukan untuk menganalisa kemampuan komunikasi matematis siswa dalam pemecahan masalah dan mendeskripsikan hal-hal lain yang berkaitan dengan hal tersebut. Karena kunci siswa dapat menyelesaikan sebuah masalah salah satunya dengan mempunyai kemampuan komunikasi yang baik.

\section{METODE}

Pada penelitian ini, peneliti menggunakan pendekatan deskriptif kualitatif. Dengan tujuan untuk mendeskripsikan kemampuan komunikasi matematis siswa dalam pemecahan masalah matematika. Penelitian ini dilakukan di kelas XI MA Darul Ulum, dengan menentukan 3 subjek penelitian dari tingkat kemampuan komunikasi yang berbeda. Penentuan subjek pada penelitian ini dilakukan dengan data observasi yang didapatkan dari informasi guru matematika terhadap masingmasing subjek, serta didukung nilai ujian akhir semester ganjil kelas XI MA Darul Ulum.

Media dalam kegiatan observasi penelitian ini adalah guru matematika karena keadaan yang tidak memungkinkan melakukan observasi secara langsung. Subjek yang terpilih kemudian melakukan tes pemecahan masalah dikuatkan dengan kegiatan wawancara. Data yang terkumpul kemudian dianalisis pada masing-masing metode. Keabsahan data pada penelitian kualitatif diuji dengan 
antara lain; uji kredibilitas, uji transferabilitas, uji dependilitas dan uji konfirmabilitas.

\section{HASIL DAN PEMBAHASAN}

Hasil

Subjek penelitian dianalisis sesuai indikator kemampuan komunikasi melalui tes pemecahan masalah dan wawancara.

Tabel 1. Kategori Subjek Penelitian

\begin{tabular}{ccc}
\hline $\begin{array}{c}\text { Kategori kemampuan } \\
\text { komunikasi matematis }\end{array}$ & $\begin{array}{c}\text { Nilai } \\
\text { subjek }\end{array}$ & $\begin{array}{c}\text { Kode } \\
\text { subjek }\end{array}$ \\
\hline Tinggi & 90 & KT \\
\hline Sedang & 82 & KS \\
\hline Rendah & 75 & KR \\
\hline
\end{tabular}

Tabel 2. Indikator kemampuan komunikasi matematis

\begin{tabular}{ll}
\hline No & \multicolumn{1}{c}{ Indikator } \\
\hline $\mathbf{1}$ & $\begin{array}{l}\text { Kemampuan menghubungkan benda nyata, gambar ke dalam bahasa } \\
\text { matematika }\end{array}$ \\
$\mathbf{2}$ & $\begin{array}{l}\text { Memahami dan mengevaluasi ide matematika dalam menyelesaikan } \\
\text { masalah secara tertulis }\end{array}$ \\
$\mathbf{3}$ & $\begin{array}{l}\text { Menggunakan simbol-simbol matematika dalam menyelesaikan } \\
\text { masalah secara tertulis }\end{array}$ \\
$\mathbf{4}$ & Menyempaikan hasil dengan baik
\end{tabular}

1. Subjek berkemampuan komunikasi matematis tinggi (KT)

Pada indikator pertama KT dapat menuliskan beberapa informasi yang diketahui dalam soal, namun tidak menuliskan pertanyaan dalam soal, hal ini menunjukkan bahwa KT sudah memahami masalah dengan baik. Pada indikator kedua, KT mampu menyelesaikan masalah dengan baik dan benar, serta menggunakan simbol-simbol dalam matematika yang merupakan indikator ketiga kemampuan komunikasi pada penelitian ini, hal tersebut dibuktikan dalam hasil tes KT yang menggunakan cara yang tepat dan menghasilkan jawaban yang benar hal tersebut menunjukkan KT dapat menyelesaikan masalah dengan baik. Hal tersebut juga diperkuat 
dengan hasil wawancara KT menjawab setiap pertanyan dengan jelas dan lugas.

2. Subjek berkemampuan komunikasi matematis sedang (KS)

KS dapat memahami informasi dalam soal, akan tetapi pada saat wawancara KS masih membacakan soal dan tidak menyebutkan apa yang menjadi pertanyaan dalam. Hal tersebut menunjukkan bahwa KS cukup baik dalam memahami masalah. Dalam merencanakan penyelesaian masalah KS sudah baik, hal tersebut ditunjukkan pada proses penyelesaian masalah KS sudah menggunakan rumus yang tepat dan menghasilkan jawaban yang benar, namun KS masih kurang menguasai materi dalam penyelesaian masalah dan dalam menjelaskan simbol-simbol matematika yang digunakan KS masih kurang memahami.

3. Subjek berkemampuan komunikasi matematis rendah (KR)

Dalam memahami masalah KR mampu menuliskan informasi dalam soal, namun tidak menyebutkan apa yang ditanyakan dalam soal. Sama halnya dengan KS, KR masih memacakan soal saat ditanyakan informasi dalam soal. KR sudah mampu merencanakan penyelesaian dengan cukup baik, hal tersebut ditunnjukkan pada proses penyelesaian KR menggunakan cara dan rumus yang benar, namun jawaban yang dihasilkan adalah salah. Serta diperkuat dengan saat kegiatan wawancara KR kurang yakin dengan jawabannya dan kurang menguasai materi. Penggunaan simbol matematika dalam penyelesaian KR sudah cukup baik, namun KR masih perlu pemahaman kembali dalam menggunakan simbol matematika.

\section{Pembahasan}

Dari analisis data yang telah dipaparkan, dapat dikemukakan bahwa KT (kemampuan komunikasi tinggi) telah mampu menyebutkan beberapa informasi dalam soal serta mengetahui hal yang ditanyakan didalamnya. Hal ini dapat dilihat dari bagaimana subjek menuliskan informasi dalam soal serta menyebutkan pertanyaan dengan benar pada saat wawancara, walaupun seharusnya pertanyaan dalam soal ditulis dalam lembar hasil penyelesaian untuk mempermudah penyelesaian masalah. Penjelasan tersebut menunjukkan bahwa KT dapat memahami masalah dengan baik, 
Dalam menentukan langkah penyelesaian, KT mampu merencanakan penyelesaian masalah dengan baik, hal ini ditunjukkan dari setiap proses penyelesaian yang benar sehingga subjek dapat melakukan perencanaan penyelesaian dengan hasil yang benar. Hal tersebut juga dilihat pada saat wawancara, KT dapat mempresentasikan dengan baik hasil kerjanya.

Selain itu, KT menggunakan simbol matematika atau bahasa matematika untuk mempermudah penyelesaian masalah, serta subjek dapat menjelaskan dengan baik setiap simbol yang digunakan. Hal tersebut menunjukkan bahwa KT mampu merepresentasi bahasa matematika dalam menyelesaikan masalah dengan baik. Dari semua proses penyelesaian masalah yang dikerjakan KT menunjukkan bahwa subjek memahami masalah dengan baik, akan tetapi pada akhir penyelesaian KT tidak menuliskan kesimpulan akhir yang seharusnya menjadi tolak ukur subjek dalam mengoreksi kembali pada setiap proses penyelesaian dan hasil yang didapatkan, walaupun hasil kerja dari KT menunjukkan hasil yang benar.

Secara garis besar dapat dikemukakan, subjek kemampuan komunikasi matematis tinggi (KT) dalam pemecahan masalah adalah; 1) Memahami masalah dengan baik ditunjukkan oleh subjek mampu menyebutkan hal yang diketahui dalam soal dan apa yang ditanyakan, 2) Perencanaan penyelesaian masalah yang cukup baik dibuktikan dengan representasi proses penyelesaian yang benar, 3) Melakukan penyelesaian sesuai rencana dengan cukup baik dibuktikan oleh hasil penyelesaian yang benar, 4) Evaluasi/koreksi kembali kepada hasil penyelesaian ditunjukkan yang kurang, dengan tidak adanya kesimpulan akhir penyelesaian. Maka subjek kemampuan komunikasi tinggi (KT) sudah menunjukkan pemecahan masalah yang baik, karena dari empat tahap pemecahan masalah, KT sudah memenuhi dengan baik tiga tahap dan satu tahap kurang baik.

Hal tersebut selaras dengan pendapat Hartati, Abdullah, dan Haji, (2017) yang menyatakan bahwa Kemampuan komunikasi matematis merupakan syarat untuk memecahkan masalah, artinya dengan sebuah komunikasi yang baik, siswa dapat memahami dan menyelesaikan suatu permasalahan dengan baik. Sedangkan pada subjek kamampuan komunikasi sedang (KS) sudah mampu menuliskan informasi pada soal dan mengetahui hal yang ditanyakan dalam soal, akan tetapi 
pada saat wawancara KS masih membaca soal dan tidak menuliskan tujuan atau pertanyaan dalam soal. Hal tersebut menunjukkan bahwa KS masih kurang memahami masalah yang diberikan. Dalam menyelesaikan masalah, KS menggunakan langkah dan rumus dengan benar, sehingga setiap proses penyelesaian masalah yang dikerjakan oleh $\mathrm{KS}$ adalah benar, hal tersebut menunjukkan bahwa perencanaan penyelesaian masalah yang digunakan KS sudah baik dan dilaksanakan dengan baik pula yang ditunjukkan dengan jawaban yang benar. Dari hasil wawancara KS cukup baik dalam memaparkan hasil kerjanya.

KS juga menggunakan simbol matematika dalam menyelesaikan masalah, akan tetapi dalam menjelaskan setiap simbol yang digunakan KS masih kurang yakin dengan jawabannya, karena KS perlu pemahaman lebih dalam menggunakan simbol atu bahasa matematika untuk menyelesaikan masalah.Pada akhir penyelesaian masalah, sebagaimana KT, KS juga tidak menuliskan kesimpulan akhir penyelesaian yang menjadi salah satu bagian terpenting dalam tahap pemecahan masalah, yaitu untuk melihat dan mengoreksi kembali proses penyelesaian yang ada apakah sudah benar-benar tepat atau masih ada yang perlu diperbaiki kembali. Hal tersebut sejalan dengan hasil penelitian Aisyah, Khasanah, Yuliani, dan Rohaeti (2018), yang menyatakan bahwa pada tahapan pengecekan kembali sebagian besar siswa melewati tahap tersebut, sehingga menjadi salah satu rendahnya tingkat pemecahan masalah yang dimiliki oleh siswa.

Secara garis besar, subjek kemampuan komunikasi matematis sedang (KS) dalam pemecahan masalah adalah; 1) Memahami masalah dengan cukup baik dibuktikan oleh subjek mampu menyebutkan informasi dari soal walaupun terkesan seperti membaca, 2) Perencanaan penyelesaian masalah yang cukup baik, hal ini ditunjukkan dengan representasi proses penyelesaian masalah yang benar, 3) Melakukan penyelesaian masalah dengan cukup baik ditunjukkan oleh hasil yang benar, 4) Tidak melakukan evaluasi kembali pada akhir penyelesaian dengan tidak adanya sebuah kesimpulan. Maka subjek kemampuan komunikasi sedang (KS) dalam pemecahan masalah adalah cukup baik. Karena pada setiap tahapan pemecahan masalah KS sudah memenuhi setengah dari keseluruhan tahap 
pemecahan masalah yang ada yaitu pada tahap memahami masalah dan melakakukan rencana penyelesaian masalah dengan cukup baik.

Pembahasan hasil analisis data pada subjek berkemampuan komunikasi rendah (KR) adalah KR mampu mengetahui informasi dari soal dengan menuliskan yang diketahui dan mampu menyebut hal yang ditanyakan. akan tetapi KR tidak menuliskan tujuan atau yang ditanyakan dalam hasil tes yang diberikan. Hal tersebut menunjukkan bahwa KR cukup baik dalam memahami masalah yang diberikan. Dalam langkah penyelesaian masalah, KR mampu merencanakan penyelesaian dengan cukup baik, yang ditunjukkan oleh penggunaan rumus yang benar, akan tetapi subjek tidak melakukan rencana penyelesaian masalah dengan baik, hal tersebut dikarenakan kurang telitinya subjek dalam mensubstitusikan nilai yang telah diketahui kedalam rumus yang digunakan, sehingga hasil yang diperoleh menunjukkan salah. Salah satu penyebab kurang telitinya KR adalah pada saat pengisian tes subjek tidak fokus pada masalah yang diberikan, akan tetapi masih memperhatikan keadaan sekitar yang menyebabkan konsentrasi KR menjadi tidak fokus.

Dalam penyelesaian masalah, KR juga menggunakan simbol matematika untuk mempermudah proses penyelesaian masalah, akan tetapi dalam menjelaskan setiap simbol yang digunakan subjek masih perlu pemahaman lebih supaya penggunaan simbol yang ada dapat mencapai tujuan yang semestinya. Proses penyelesaian masalah yang dikerjakan oleh KR adalah cukup baik. Kurangnya pemahaman dalam menjelaskan simbol-simbol matematika juga dijelaskan pada hasil penelitian Irfan (2017) bahwa kesalahan dalam memaknai simbol-simbol yang digunakan dalam menghambat pada pemecahan masalah. Namun KR sudah menggunakan langkah yang benar dalam menyelesaikan masalahnya.

Hal tersebut ditunjukkan dengan langkah-langkah yang digunakan sudah tepat, tetapi pada akhir penyelesaian, KR kurang teliti untuk menentukan nilai yang diperintah sehingga hasilnya salah. Tidak adanya evaluasi atau koreksi ulang dari subjek menjadi salah satu sebab kesalahan yang ada. Oleh karena itu, menuliskan kesimpulan akhir penyelesaian adalah salah satu bentuk koreksi ulang pada setiap langkah penyelesaian. Secara keseluruhan dikemukakan bahwa, 
subjek kemampuan komunikasi matematis rendah (KR) dalam pemecahan masalah adalah; 1) Memahami masalah dengan cukup baik ditunjukkan dengan subjek dapat menyebutkan informasi dari soal, 2) Perencanaan penyelesaian masalah yang cukup, dibuktikan oleh representasi proses penyelesaian soal dengan sebagian menggunakan cara keliru/kurang tepat, 3) Melakukan penyelesaian masalah dengan kurang maksimal karena terdapat hasil yang salah, 4) Tidak adanya kesimpulan menyebabkan sebagian hasil penyelesaian yang salah serta subjek tidak melakukan evaluasi kembali terhadap hasil kerjanya. Maka subjek kemampuan komunikasi rendah (KR) dalam pemecahan masalah adalah cukup. Karena dari empat tahap pemecahan masalah KR hanya memenuhi dengan baik pada satu tahap yaitu pada tahap memahami masalah. Hal ini juga didukung dengan pemaparan guru matematika pada saat pembelajaran, subjek masih terlihat pasif dalam bertanya ataupun saat menyampaikan pendapatnya.

Kemampuan komunikasi yang baik akan mengantarkan siswa kepada pemahaman dan pemecahan masalah dengan baik pula. Kemampuan komunikasi matematis siswa merupakan suatu cara siswa untuk mengomunikasikan ideidenya dalam usaha memecahkan masalah yang diberikan oleh guru, serta berpartisipasi aktif dalam diskusi, dan mempertanggung jawabkan jawaban mereka terhadap suatu masalah. Karena komunikasi juga memberikan pelajaran penting untuk siswa, supaya siswa dapat meyakinkan dirinya bahwa dia mampu untuk meyampaikan apa yang telah mereka pahami dalam proses pemecahan masalah tersebut (Dewimarni, 2013).

\section{SIMPULAN}

\section{Kesimpulan}

Berdasarkan hasil dan pembahasan penelitian yang telah dipaparkan maka, kesimpulan dari penelitian ini sebagai berikut; 1) Siswa berkemampuan komunikasi matematis tinggi mempunyai kemampuan pemecahan masalah yang baik, 2) Siswa kemampuan komunikasi matematis sedang mempunyai kemampuan pemecahan masalah yang cukup baik, 3) Siswa kemampuan komunikasi matematis rendah mempunyai kemampuan pemecahan masalah yang cukup. Secara garis besar disimpulkan bahwa tingkat kemampuan komunikasi matematis yang berbeda mempunyai kemampuan pemecahan masalah berbeda. 


\section{Saran}

Kemampuan komunikasi matematis siswa sangat menarik untuk diteliti, karena salah satu kunci suksesnya tujuan pembelajaran terletak pada kemampuan komunikasi antara siswa dan guru. Oleh karena itu, harapan dari hasil penelitian ini bisa dijadikan sebagai acuan penelitian selanjutnya dengan variabel lain yang menarik untuk dikaji bersama kemampuan komunikasi matematis seperti rasa percaya diri siswa saat memaparkan pendapatnya didepan kelas, karena pengalaman penelitian ini sebagian siswa masih tidak yakin dengan kemampuannya untuk menyampaikan pendapatnya

\section{DAFTAR RUJUKAN}

Abdullah, A. H., Abidin, N. L. Z., \& Ali, M. (2015). Analysis Of Students' Errors In Solving Higher Order Thinking Skills (HOTS) Problems For The Topic Of Fraction. Asian Social Science, 11(21), 133-142. Https://Doi.Org/10.5539/Ass.V11n21p133

Aisyah, P. N., Khasanah, S. Umi N., Yuliani, A., \& Rohaeti, E. E. (2018). Analisis Kemampuan Pemecahan Masalah Matematis Siswa SMP Pada Materi Segiempat Dan Segitiga. JPMI (Jurnal Pembelajaran Matematika Inovatif), 1(5), 1025. Https://Doi.Org/10.22460/Jpmi.V1i5.P1025-1036

Anggo, M. (2011). Pelibatan Metakognisi Dalam Pemecahan Masalah Matematika. Edumatica, 01(April), 25-32.

Hartati, S., Abdullah, I., \& Haji, S. (2017). Pengaruh Kemampuan Pemahaman Konsep, Kemampuan Komunikasi Dan Koneksi Terhadap Kemampuan Pemecahan Masalah. MUST: Journal Of Mathematics Education, Science And Technology, 2(1), 43. Https://Doi.Org/10.30651/Must.V2i1.403

Haryani, D. (2011). Pembelajaran Matematika Dengan Pemecahan Masalah Untuk Menumbuhkembangkan Kemampuan Berpikir Kritis Siswa. Prosiding Seminar Nasional Penelitian, Pendidikan Dan Penerapan MIPA, (1980), $121-126$.

Husna, Ikhsan, M., \& Fatimah, S. (2013). Peningkatan Kemampuan Pemecahan Masalah Dan Komunikasi Matematis Siswa Sekolah Menengah Pertama 
Melalui Model Pembelajaran Kooperatif Tipe Think-Pair-Share (Tps). Jurnal Peluang, 1(2), 81-92.

Irfan, M. (2017). Analisis Kesalahan Siswa Dalam Pemecahan Masalah Berdasarkan Kecemasan Belajar Matematika. Kreano, Jurnal Matematika Kreatif-Inovatif, 8(2), 143-149. Https://Doi.Org/10.15294/Kreano.V8i2.8779 Surur, M., Degeng, I. N. S., Setyosari, P., \& Kuswandi, D. (2020). The Effect Of Problem-Based Learning Strategies And Cognitive Styles On Junior High School Students' Problem-Solving Abilities. International Journal Of Instruction, 13(4).

Syelfia Dewimarni. (2013). Analisis Kemampuan Komunikasi Padangdan Pemahaman Konsep Aljabar Linier Pada Mahasiswa Universitas Putra Indonesia 'YPTK.' Al-Jabar: Jurnal Pendidikan Matematika, 8(1), 53-62. Retrieved From Http://Ir.Obihiro.Ac.Jp/Dspace/Handle/10322/3933

Tefa, S., Idayani, D., \& Astindari, T. (2019). Perbandingan Hasil Belajar Siswa Antara Pemberian Tugas Kelompok Dan Tugas Individu Pada Mata Pelajaran Matematika Di Smp Negeri 6 Situbondo. EDUSAINTEK: Jurnal Pendidikan Sains Dan Teknologi, 6(1), 23-33.

Wardhana, I. R., \& Lutfianto, M. (2018). Analisis Kemampuan Komunikasi Matematis Siswa Ditinjau Dari Kemampuan Matematika Siswa. UNION: Jurnal Ilmiah Pendidikan Matematika, 6(2), 173-184. https://doi.org/10.30738/.v6i2.2213 